\title{
DEVELOPMENT OF THE INTELLECTUAL POTENTIAL OF THE NATION IN THE FORMATION OF AN INNOVATIVE ECONOMY
}

\section{Sanaliyeva Laura}

Teacher, European National University named after L.N.Gumilyov Astana, Kazakhstan

Аннотация. Казахстан в XXI веке стремится стать конкурентоспособной нацией в создании идей и новых технологий. Именно молодежь в будущем будет определять уровень развития страны и ее экономический успех.

Annotation. Education in the modern period becomes the sector of the economy, and the main resource for the development of the economy is the human factor - the most valuable person that can open up, create something new in production, science, culture, etc. Therefore, the most important mission of higher education in Kazakhstan is training intellectually developed, creatively working professional citizens of the Republic of Kazakhstan.

Ключевые слова: интеллект, нация, интеллектуальный потенциал, экономика, инновация, развитие, образование, формирование , развитие

Keywords: intelligence, nation, intellectual potential, economy, innovation, development, education, formation, development

The head of state has repeatedly noted the priority of schools with a uniquegrade in the field of natural science, mathematics and computer science. Nowadays in our country there are more than 20 intellectual schools. Similar schools are open in all over the world. In the 21st century Kazakhstan is aspiring to become a competitive nation in creating ideas and new technologies.Just young people will determine the level of development of the country and its economic success in the future. For example, In China in all provinces there are very strong specialized schools. It is a concern of the state about the development of its intellectual nation.

In the modern world, there is an increase of social orientation of economic policy in developed and developing countries.For many countries, strategic economic aims in the field of economy become very similar, namely:

- stable economic growth;

-creating conditions for increasing employment and reducing unemployment; -content of inflation; 
-security of high competitiveness of products;

-prosperity and maintenance of relatively high standards of living and social guarantees.

At the same time, it is foreseen, first of all, increasing social investments in a person, training and maintaining health.

The formation of the leading countries of the world led to the development of a postindustrial, and then a new economy, it is the economy, innovation, the global information system, the economy of intellectual labor, education, science and new technologies. The basis of this new economy is intellectual potential, which is the main dominant socio-economic development of modern society.

Education in the modern period is becoming a branch of the economy, and the main resource for the development of the economy is the human factor - the most valuable person that can open up, create something new in production, science, culture, etc.Therefore, the most important mission of higher education in Kazakhstan is the training of intellectually developed, creatively working professional citizens of the Republic of Kazakhstan.

The need to understand social change is acutely felt by all sociologists.The most important features of the modern stage of social change are intensive globalization, the growth of technological, natural and sociogenic risks.The results of large-scale empirical research will undoubtedly become the basis for constructing the concepts of transforming a multi-layered Kazakhstan society and pragmatic technological regulation of the modern historical process.This is the basis for increasing the prestige of sociological knowledge in circles of power and the general public.

Fashion for the intellect begins: "Fashion for the intellect gradually begins, although, alas, it has its own costs: there will be inevitable snobbery, circles and intellectual initiative (what to do, we ourselves destroyed almost the entire environment where smart teenagers could gather and argue).But all these growing diseases should not obscure the main thing: over the past five years, teachers' complaints about the level of applicants and employers at the graduate level were simply inevitable ... as always happens with stagnation, self-education has become 
the main occupation of the community and brought the first results. Young people, simply demanding due to inexperience, quickly became bored just to consume and entertain." [2].

Today intellect is becoming the most important factor in the development of society and the expansion of economic activity. The study is aimed at economists and managers, as well as readers interested in the role of intelligence in the development of modern economics.

One of the main tasks of the state in a creative society is the full development of its intellectual potential, of which the human potential is a special part. The economy of a creative society should be socially oriented, market-oriented and innovative.

At present, the concepts of intellectual capital and intellectual potential are actively developing at different levels of the economy and society.

The intellectual potential of society is formed and developed by a system of education, training, advanced training and retraining, self-education, science, research and development, as well as using methods, tools, tools and mechanisms that are used to create and implement solutions in various fields.

Specialists of the team and organizations in general should have:

) special knowledge that is acquired in obtaining special education;

2) professional experience, knowledge, and skills obtained in the course of practical activities;

3) intellectual and creative abilities;

4) responsibility for the quality of work;

5) performance when performing tasks;

6) communication skills in the enterprise and beyond, the ability to negotiate and influence people;

7) the ability to work in a team, goodwill;

8) leadership abilities[3].

In the long term, the implementation of the country's economic development strategy should be based on the choice of the main directions of industrial policy, priority sectors and their investments. For the transition to an innovative economy 
based on knowledge, creativity and intelligence, it is necessary to activate human capital as the most important factor and valuable resource of the national wealth of society.

Optimal interaction between the educational authorities and the training of qualified personnel in accordance with the demands for production requires special training and retraining of workers based on continuous monitoring of current trends. The implementation of innovative projects of innovative industrialization is carried out by creating new jobs that require highly skilled professionals.

To transform the new quality of human capital, it is necessary to radically reform the existing system of personnel training and retraining and increase investment in this area.

Accelerated formation of competitive human capital is possible with the achievement of stability in the economy and sustainable post-crisis economic development of the country, because it means a targeted restructuring of employment based on high-tech industries. Therefore, ensuring the long-term sustainable economic development of the country to meet the challenges posed by accelerated innovative industrialization is of paramount importance.

Unfortunately, the programs of scientific institutions and innovative projects in the republic are not interconnected. Scientific organizations conduct research and development on their programs. Thanks to government programs and internal resources of the enterprise, technological innovations are introduced at the expense of their costs. Programs of research and innovation are scattered, the subjects of ownership are different.

The strategic task of the state science and technology policy at the new stage of development of Kazakhstan should be aimed at:

- the definition of science as one of the strategic priorities of the socio-economic development of the country;

- development of priority research aimed at obtaining practical results at the level of world achievements; 
- stimulation of the susceptibility of the economy to innovation (stimulating demand) [4].

The consequence of a link to an innovative development model will be:

- a gradual increase in economic growth rates as a result of attracting and mastering advanced technologies of the fifth and sixth models, overcoming the consequences of the global economic crisis;

- narrowing the gap in economic and technological development with developed countries, which will increase the level and quality of life of the population;

- ensuring the progressive structural changes in the national economy, the development of institutions, overcoming the manifestations of the shadow economy and corruption, the excessive exclusion of the financial sector from the real economy;

- strengthening the social and environmental orientation of the economy, the similarity of the national economic system with the systems of other countries.

Thus, the formation of a strategic priority for the creation of competitive human capital and its successful implementation is one of the main resources for ensuring accelerated industrial and innovative development of the country, post-crisis recovery and stability of the national economy.

\section{LITERATURE}

[1] Nazarbayev N.A. Social modernization of Kazakhstan: Twenty steps to the Commonwealth of Universal Labor // http: //www.kazpravda. kz / c / 1341882404.

[2] Qualified staff - to industrial Kazakhstan // Kazakhstan's truth. - 2010. - 5 June. (In Russian).

[3] Zhuravlev V.A. Creative Society - a New Paradigm for the Development of Countries in the 21st Century // Creative Economy. - 2008. - No. 11.ISBN978-591292-037-0.(In Russian).

[4] http://e-history.kz/en/contents/view/1064(In Russian). 